\title{
The Regional Concentration of Industries and the Performance of Firms: a Multilevel Approach
}

\author{
Fernando C oelho M artins Ferreira * \\ E-mail address: fferreira@ mackenzie.br \\ Instituto Presbiteriano M ackenzie and Fundação Getulio V argas - EAESP/FGV \\ São Paulo, SP, B razil.
}

\section{R afael G. B urstein G oldszmidt}

E-mail address: rafael.goldszmidt@fgv.br

Escola B rasileira de A dministração Pública e de E mpresas/Fundação Getúlio V argas - EB A PE/FGV

Rio de J aneiro, RJ , Brazil.

\section{J oão M ario C sillag}

E-mail: joao.mario.csillag@fgv.br

Escola de A dministração de Empresas de São Paulo /Fundação Getúlio V argas - EAESP/FGV

São Paulo, SP, Brazil.

\begin{abstract}
This paper presents the results of a study whose objective was to understand how location within industrial concentrations, like clusters or industrial districts, affects the financial performance of firms. In its theoretical framework, this paper attempts to introduce the reasons behind the alleged superior performance of firms located in these concentrations, the base of the hypothesis formulated in this study. Analysis from a three-level hierarchical linear model applied to a sample of 509 companies located in the state of São Paulo found no evidence that industrial concentrations provide firms with superior performance, contradicting expectations generated by the theory. The decomposition of the variance of performance indicated that the location of the firms and the form with which a city interacts with an industry exerts significant influence on how they will perform. In short, location matters to the future of firms. This finding underlines the need to understand how characteristics of cities or regions can promote or retard the performance of firms.
\end{abstract}

Key words: location; industrial concentrations; clusters; financial performance; multilevel model.

Received 26 A ugust 2009; received in revised form 19 J anuary 2010.

Copyright (c) 2010 Brazilian A dministration R eview. All rights reserved, including rights for translation. Parts of this work may be quoted without prior knowledge on the condition that the source is identified.

\footnotetext{
* Corresponding author: Fernando Coelho M artins Ferreira Instituto Presbiteriano M ackenzie, CCSA, Rua da Consolação, 930, Prédio 60, B airro da Consolação, São Paulo, SP, 01302-907, B razil.
} 


\section{INTRODUCTION}

The regional concentration of industries, i.e. the location of a few, well-defined industrial sectors in a region (B rakman, Garretsen, $\&$ M arrevijk, 2001), is a phenomenon that is far more common than usually imagined, and not just limited to such classic examples like Silicon V alley and Route 128. The reasons for their origins can be linked to very distinct factors. While some industries may be concentrated in a region due to the availability of specific resources, proximity to consumer markets, or even as a historical accident, other industries do not have any natural tendency towards a concentrated location (M ori, Nikishimi, \& Smith, 2005).

Clusters and Industrial Districts, the concepts most commonly associated with the phenomenon of regional concentrations, obtained a projection that exceeded academic boundaries. Vom Hofe and Chen (2006) state that since the early 1990s analyses of industrial clusters as a new alternative strategy of economic development have proliferated. Clusters, and their like, have been recognized as a source of competitive advantage, capable of leveraging the competitiveness of countries and regions and providing firms located within their borders with superior performance (Boasson, Boasson, M acpherson, \& Shin, 2005).

Perhaps the strongest reason for the growing interest in industrial concentrations is precisely the emergence of evidence suggesting that location in these regions can provide superior performance to firms (A rikan, 2009). In the literature, examples abound of studies confirming a positive relationship between industrial concentration and performance. Within some more recent research, operational measures such as innovation rates (Caner \& Hall, 2006; Porter, 2003; Saxenian, 1996) and staff turnover (Fallick, Fleischman, \& Rebitzer, 2006) have been used to establish this relationship. Others have confirmed the influence of industrial concentration through measures of growth, such as the growth of demand (Chung \& K alnis, 2001), wages (Porter, 2003) and jobs (Brito, B rito, Szilagyi, \& Porto, 2008; Holmes \& Stevens, 2002; Porter, 2003). Even the market share of companies was used to confirm this relationship (Sakakibara \& Porter, 2001).

The results of these and several other studies may suggest that the evidence in favor of location in concentrations is unquestionable. However, these studies, prevalent as they are, have begun to share room with research that, at the very least, questions this relationship.

$M$ any of the researchers who raise this question point out the methodological weaknesses of some of these studies. Some authors, for example, claim that the supposed positive relationship between concentration and performance has little empirical support, emphasizing that the lack of systematic data and appropriate measures of performance undermine the reliability of studies that claim such a relationship (A ppold, 1995; M almberg \& Power, 2005). Several of the models used in these studies suffer from serious problems of estimation, casting doubt on the findings derived from them (Hanson, 2001).

Pouder and J ohn (1996) observed biased results in several studies that found a positive relationship between industrial concentration and performance. Their analyses referred only to periods in which concentrations were not subjected to any kind of crisis, without considering the performance of clustered firms in trying times.

A ppold (1995), when analyzing a random sample of almost 1,000 firms in the metallurgy industry, found no evidence to support the hypothesis of superior performance in terms of concentrations. Furthermore, no objective outcome was found to support the recurring idea that the small and medium sized businesses within the concentrations were able to overcome the limitations intrinsic to their nature, such as the lack of economies of scale (B ecattini, 1991; Boschma \& Lambooy, 2002). These authors, however, are not the only ones who present contrary evidence concerning a positive relationship between localization within industrial concentrations and performance. Dekle (2002), Ferreira (2005) and George and Zaheer (2006) are other examples of studies that accordingly add to the list. 
Contradictory evidence in studies of the relationship between industrial concentration and performance open avenues for conducting studies that explore the effect of location in concentrations on the performance of firms from another perspective.

The main objective of this work is to measure the resulting effect of location in concentrations, comparing the results obtained with those of companies that are not in areas of regional concentration. Therefore, the unit of analysis is the firm. In order to compare the performance of concentrated companies with companies that are geographically isolated, financial measures which are directly or indirectly related to the bottom line of companies' performance will be used.

A lthough some industrial concentrations might evolve into clusters or industrial districts, this study will still treat all these correlated phenomena as essentially industrial concentrations in order to avoid the risk of giving them the wrong classification within the taxonomy of industrial concentrations, as recommended by some authors (Ferreira, 2005; M artin \& Sunley, 2003; V an Der Linde, 2002).

This paper is structured as follows: first, the literature review is presented, which forms the basis for structuring the hypotheses of this study; this is followed by the research methodology; finally, the results of the study are presented along with their primary implications and the study's limitations.

\section{LITERATURE REVIEW}

$M$ arshall (1985) was a pioneer in establishing a relationship between concentration and performance. $\mathrm{He}$ noted that firms that were concentrated in some regions of England benefited from certain advantages when compared to those that lay outside these concentrations. Examples of these advantages included savings in equipment and labor costs and a higher capacity for innovation.

The concentrated areas, from that moment on, gained recognition as an environment characterized by a large flow of knowledge, intense specialization of labor and the existence of a large network of subsidiary industries and specialized machinery ( $M$ arshall, 1985), enabling them to provide products and services at competitive costs (Floysand \& J akobsen, 2002; Y ou \& W ilkinson, 1994).

These characteristics would generate cost efficiencies in companies that were geographically concentrated, derived from economies of scale and the specialization of labor and technology, or a combination of these factors (Hoover, 1948). Once a concentration is established, the returns to scale achieved by firms regionally concentrated would stimulate the establishment of new firms in the region (M artin \& Sunley, 1996; Porter, 1998a).

These pecuniary externalities, achieved when the presence of a new firm results in positive returns (profits) for all firms (M eardon, 2000), would be critical in location decisions (K rugman, 1993). However, these would not be the only externalities from which geographically concentrated firms would benefit. There would also be externalities associated with the direct - non mediated by the market - interdependence of firms (Scitovsky, 1954).

These economies, also known as dynamic or technological externalities, would have significant impact on innovation and growth, as well as carrying considerable weight in the location decisions of businesses (Henderson, K uncoro, \& Turner, 1995; K etelhohn, 2002).

These dynamic externalities would be the result of a long history of interactions among concentrated firms, leading to the construction of distinct knowledge, capable of creating value available only to concentrated firms (B enneworth, 2002; Hakanson, 2004; Porter, 1998b), due to its tacit, non codified character (Boschma \& Lambooy, 2002; Feser \& Bergman, 2002). The repeated interactions and informal contracts stimulate trust and open communication, reducing the costs of controlling and recombining market relationships (Floysand \& J akobsen, 2002; Porter, 1998c). 
Furthermore, the concentrations would have the potential to increase productivity and the rate of innovation of the firms located within their borders, thus leading to self expansion and strength (Porter, 1998a). G reater flexibility of products and processes and a larger reputation would be other potential benefits of locating within industrial concentrations (Corolleur \& Courlet, 2003; M olinaM orales \& M artínez-Fernández, 2003; Pietrobelli \& B arrera, 2002).

L ocation, therefore, is recognized as a factor that directly affects the competitive advantage of firms (Porter, 1998c), and industrial concentrations, in this context, would provide superior performance to their firms (B oasson et al., 2005).

\section{Concentrated Firms and the Conversion of Assets into Profit}

The importance given to the issue of location seems to justify the increasing geographic concentration of firms, as well as the accumulation of empirical evidence demonstrating the influence of geography on the results of firms, positioning itself as a key factor in defining the boundaries of the competitive landscape (A rikan, 2009).

The term competitiveness has been used in a general way to refer to the performance of firms. Therefore, at the firm level, competitiveness has a relatively clear meaning, referring to the ability of a company to compete, grow and be profitable in the market in which it operates (B ristow, 2005).

In studies on the composition of the performance variance of firms, the Return on Assets [ROA ] and Operational Return on Assets [OpROA] are among the most common indicators of profitability (M cgahan \& Porter, 1997; R umelt, 1991). The rate of Return on A ssets [ROA] measures the overall efficiency of the company in generating profit from its available assets (Gitman, 2001). It can be interpreted in two ways. First, ROA measures the firm's capacity and efficiency for using its available assets to generate profits. Second, it reports the total return financed by capital providers (Iiabilities and equity), regardless of the source of capital (White $\&$ Sondhi, 1997). The ROA is commonly expressed as follows:

$$
R O A=\frac{\text { Net Income }(\text { After Income Tax })}{\text { Total Assets }}
$$

A ssuming that a company has an ROA index of 0.11 , it means that it has been able to convert the equivalent of $11 \%$ of the total value of its assets into net income.

As observed at the beginning of this section, location economies provide firms with a series of gains in cost, resulting in gains of scale, specialization of labor and better use of technologies and resources. However, these economies are not manifested only by gains in cost, but also by superior innovation and productivity, forged by a long history of interactions and relationships between firms, capable of enhancing the creation of value for companies operating in concentrations. L ower costs combined with higher productivity and creation of value would form the conditions necessary for firms located in industrial concentrations to have a performance superior to those firms not located in concentrations. This is the first hypothesis of this study.

Hypothesis 1: The companies located in industrial concentrations have a rate of return on assets [ROA] superior to that of firms not located in industrial concentrations.

The use of net profit for the calculation of ROA, however, may offer a false perception as to the potential for generating profit from the operations of a company. This is possible because, on the basis of calculating the net profit, there may be some non-operational revenues and expenses included, as well as payments resulting from participations, contributions and donations. In short, these additions and deductions reported after operating profit may cause some firms to appear less profitable than they actually are (White $\&$ Sondhi, 1997). To avoid this problem, one possible solution is the use of Operating Return on Assets [OpROA], which takes the firm's operating profit rather than net income 
into account in order to measure the actual capacity of a company to generate profits with its operational activities. Expressed as a formula:

$$
O p R O A=\frac{\text { operating profit }}{\text { Total assets }}
$$

Additionally, a secondary hypothesis, related to the operating profit of firms, is presented in an attempt to avoid the noise derived from expenditures and revenues not related to their core activities.

Hypothesis 1.1: The companies located in industrial concentrations have a rate of return on operating assets [OpROA] superior to that of firms not located in industrial concentrations.

\section{Concentrated Firms and the Efficiency of Their Assets}

The R eturn on A ssets [ROA] of a firm has a direct relationship with its assets turnover (here named ASSETURN), which is a general measure of efficiency of the investment of a company, considering the impact of short and long-term assets (White \& Sondhi, 1997). In other words, it represents the capacity that the company has to convert its assets into sales, calculated as follows:

$$
\text { Assets Turnover }=\frac{\text { Sales }}{\text { Total Asset }}
$$

One of the possible ways to calculate the ROA of a firm is to multiply the product's profit margin by the asset turnover, which is known in literature as the Du Pont equation (Brigham, Gapensky, \& Ehrhardt, 1999), as can be seen below:

$$
\text { ROA }=\text { Profit Margin } x \text { Asset Turnover }
$$

or

$$
R O A=\frac{\text { Net Profit }}{\text { Sales }} \times \frac{\text { Sales }}{\text { Total Assets }}
$$

This way of calculating the ROA shows the ability of assets turnover in leveraging the profitability of companies. Therefore, assuming net margins constant, the higher the asset turnover, the better the performance of that company will be in terms of ROA.

Companies located in industrial concentrations may see a larger increase in sales as opposed to those of firms not located in concentrated areas (Federação das Indústrias do Estado de São Paulo [FIESP], 2008), which would directly affect the asset turnover. Concentrated firms could take advantage of the reputation associated with some concentrations (M olina-M orales \& M artínez-Fernández, 2003), as well as the flexibility of their products and processes (Corolleur \& Courlet, 2003; Pietrobelli \& Barrera, 2002; Y ou \& Wilkinson, 1994) to increase their sales. The greater capacity for innovation could also be reflected in higher sales through the creation of products and services of greater value (Benneworth, 2002; Hakanson, 2004; Porter, 1998a, 1998b).

Moreover, the asset turnover can be leveraged through the reduction of the total assets of the company. In this sense, the existence of an extensive network of suppliers and specialized machines in the concentration would allow the outsourcing of certain operational and non-operational activities (K otval \& M ullin, 1998; M arshall, 1985; Porter, 1998a; Y ou \& W ilkinson, 1994), thereby decreasing the need for fixed assets and, consequently, the total assets of the companies.

B oth increased sales and reduced total assets could work in favor of the firm's asset turnover. The supposed benefits arising from location in industrial concentrations would provide firms with a higher asset turnover when compared to firms that are not concentrated. 
Hypothesis 2: Companies located in industrial concentrations have a rate of asset turnover (ASSETURN) superior to that of firms not located in industrial concentrations.

\section{METHODOLOGY}

The verification of the existence of a positive relationship between industrial concentrations and performance requires the development of a variable that discriminates between firms located in industrial concentrations and those that are isolated. It is therefore necessary to resort to a methodology in order to identify regions characterized by the concentration of any productive activity.

Several studies (Audretsch \& Feldman, 1996; Britto \& Albuquerque, 2002; Crocco, Galinari, Santos, Lemos, \& Simões, 2006; Hoen, 2000; Instituto Paranaense de Desenvolvimento Econômico e Social [IPARDES], 2005; Krugman, 1991; Puga, 2003; Serviço de A poio às Micro e Pequenas Empresas [SEBRAE], 2002; Suzigan, Furtado, Garcia, \& Sampaio, 2003) have proposed methodologies for distinguishing industrial concentrations. Since there are significant similarities between the methodologies for identification of industrial concentrations, the model proposed by Puga (2003) has been chosen for use in this study.

Basically, the methodology of Puga (2003) makes use of two indicators: the quotient of location [QL ], which is a specialization index of the region, and the Gini coefficient [GINI], which aims to measure the degree of concentration of an industry within a specific region, in accordance with K rugman (1991) and A udretsch and Feldman (1996). Puga (2003) also requires a minimum amount of establishments and jobs to confidently classify a region as an industrial concentration.

In this work, the QLs and Ginis were calculated from data on jobs from the RAIS (acronym for Relação A nual de Informação Sociais, Y early Social Information Report) database, published by the Brazilian M inistry of Labor and Employment. The selected data include all formal jobs of the 99 economic activities of the manufacturing industry, ranging between the 3-digit CNAEs (the Brazilian version of Standard Industry Classifications [SICs]) 151 and 372, in 645 cities in São Paulo State from 1996 to 2005. Data on the numbers of establishments per industry-city interaction were also obtained from the same database.

This study used data concerning jobs and establishments for ten consecutive years, unlike the study of Puga (2003), whose data included just one year of observation. This study considered only industrycity interactions that, in the years of 1996 to 2005, met the criteria of Puga (2003) for at least six years. After delimiting this scope and applying the selected criteria, 489 industry-city interactions that could be considered industrial concentrations were obtained.

Thus, the dummy variable CONC was defined with a value of 1 for the industry - city interactions that are characterized as industrial concentration and 0 for others.

\section{Dependent Variables}

Performance was operationalized by three indicators: net income divided by assets (ROA) and operating income divided by assets (OpROA), in accordance with the majority of previous studies on the composition of the performance variance (McGahan \& Porter, 1997; Rumelt, 1991) and asset turnover (ASSETURN).

The performance database of firms was provided by SERA SA, an analysis and information company for credit decisions and support for businesses. It provided a database of companies located in Sao Paulo whose economic activities were previously characterized by the presence of industrial concentrations. 
Originally, the base contained 8,637 records pertaining to 1,569 firms located in 76 cities, belonging to 59 different CNAEs. This database contained variables concerning the accounting and financial results of these companies for up to ten consecutive years. It is important to highlight that the sample is composed both by companies located in concentrations as well as outside of them, so that the results of the two groups can be compared. Initially, the concentration variable (CONC) was inserted into the base, which was submitted to a data screening process. Using a process similar to that proposed by Goldszmidt, B rito and V asconcelos (2007), it was established that: (1) companies should have at least four years of observation; (2) there should be at least two firms in each industry-city interaction; (3) outliers in each of the measures of performance would be eliminated, defined by the values of ROA or OpROA greater than 1.00, less than -1.00 and asset turnover greater than 8 . By applying these filters, the database of SERASA was reduced to 4,280 records, representing 509 firms belonging to 23 different industries or CNAEs, located in 46 cities of the state of Sao Paulo. Thirty eight (38) of the 509 firms in the sample (or $7.47 \%$ of the total) were located in industrial concentrations.

\section{Analytical Method}

The variability of firm performance can be explained by variables at different levels of aggregation. Some, for example, characterize attributes specific to firms (such as size), which distinguish between companies that operate in the same industry. Other variables, at a more aggregated level, characterize industries (such as the degree of concentration) and are common to all firms that compete in the same industry. Firms that operate in the same geographical area, in turn, share regional characteristics (such as the quality of local infrastructure, strength of institutions, etc.). Finally, some variables are not simply related to one industry or one city, but to a specific combination of industry and geographical region, a category to which industrial concentrations and clusters belong. This hierarchical organization of observations requires the use of a specific statistical technique.

According to Hoffman (1997), there are basically three alternatives for the analysis of data at multiple levels. The first of these consists of disaggregation of data, associating the same value to each case within the same group, which is obtained from the higher level. A non-hierarchical model of analysis would then be used for individual cases. This strategy has been widely used when applying linear regression models with a dummy variable indicating an industrial concentration that assumes the same value, 1, for all firms located in concentrations. However, this approach violates the assumption of independence of observations, which implies an underestimation of the magnitude of standard errors of estimates (Hox, 2002).

The second alternative consists of using mean values. This approach is also found in the analysis of the relationship between performance and industrial concentrations, when studying any indicator of mean performance by industry-city interaction rather than the individual performance of each firm. In these cases, the variability in performance among firms in the same industry-city interaction is ignored.

Finally, the multi-level models, also known as hierarchical models, have as a main advantage the recognition of the hierarchical nature of the data, which allows the inclusion of explanatory variables at the appropriate level. The industrial concentration, a variable that characterizes a combination of industry and city, would be included at the industry-city interaction level, while the size of each firm, for example, would be considered as a variable at the firm level. A Ithough frequently used in research fields such as Education, the application of hierarchical models in $M$ anagement is quite recent (Hough, 2006; Short, K etchen, Palmer, \& Hult, 2007). These models can bring diverse benefits to the analysis of the relation between industrial concentrations and performance, which are discussed in the following section.

\section{The Proposed M odel}

The model adopted in this study is based on the structure used by Goldszmidt, Brito and $V$ asconcelos (2007) to analyze the home country effect. The main interest of this study is industry-city 
interaction, as part of this effect may be a result of the existence of industrial concentrations or clusters. This interaction captures the influence of all attributes that are specific to an industry in a city, which is added to the main effects of industry and city. Industry attributes may affect the performance of firms in this industry in several locations, while the characteristics of a particular city may influence firms of diverse sectors located in this city. On the other hand, some properties of a particular industry in a specific city may affect firm performance. The effect of the presence of a regional concentration of an industry in a city, for instance, would not be accounted for by the city and industry effects, but only by their interaction.

The main effects of industry and city must also be controlled in the model, in order to keep the specific characteristics of an industry or a city from contaminating the conclusions related to industrycity interactions. The city and industry effects should be considered as cross-classified within the same level, since there is no hierarchical relationship between them. Thus, the highest level should include the main effects for cities and industries, as well as the industry-city interaction. Firms are nested in the industry-city interactions and, finally, the annual observations are nested in firms.

Thus, a three level model is considered, with cities $(I)$, industries $(k)$ and city-industry interactions (kl) at Level 3; firms (j) at L evel 2; and the years (i) at Level 1. Formally:

\section{L evel 1}

$$
\text { Performance }_{i j k l}=\pi_{0 j k l}+e_{i j k l} \quad e_{i j k l} \sim N\left(0, \sigma_{e}^{2}\right)
$$

where $\pi_{0 j k l}$ is the mean performance of the firm $j$ e $e_{i j k l}$ is the deviation from the mean performance of the firm in the year $i$.

\section{Level 2}

$$
\pi_{0 j \mathrm{kl}}=\beta_{00 \mathrm{kl}}+\mathrm{r}_{0 \mathrm{jkl}} \quad \mathrm{r}_{0 \mathrm{jkl}} \sim \mathrm{N}\left(0, \sigma_{\mathrm{r}}^{2}\right)
$$

where $\beta_{00 \mathrm{kl}}$ is the mean performance of firms of industry $\mathrm{k}$ from city I and $\mathrm{r}_{0 \mathrm{jkl}}$ is the deviation from the mean performance of firm $j$ relative to this mean.

\section{Level 3}

$$
\begin{array}{ll}
\beta_{00 \mathrm{kl}}=\gamma_{0000}+\mathrm{s}_{000 \mathrm{k}}+\mathrm{t}_{000 \mathrm{l}}+\mathrm{u}_{00 \mathrm{kl}} & \\
& \\
\mathrm{s}_{000 \mathrm{k}} & \sim \mathrm{N}\left(0, \sigma_{\mathrm{s}}^{2}\right) \\
& \mathrm{t}_{000 \mathrm{l}} \sim \mathrm{N}\left(0, \sigma_{\mathrm{t}}^{2}\right) \\
& \mathrm{u}_{00 \mathrm{kl}} \sim \mathrm{N}\left(0, \sigma_{\mathrm{u}}^{2}\right)
\end{array}
$$

where $\gamma_{0000}$ is the grand mean of performance, $s_{000 k}$ is the residual of industry $k$ in relation to this mean (Industry effect), $t_{000 l}$ is the residual of city I relative to this mean (city effect) and $u_{00 k l}$ is the residual of industry-city interaction k - City I (Industry-City Interaction Effect). In compact notation:

\section{Eq. 1}

$$
\text { Performance } e_{i j k l}=\gamma_{0000}+s_{000 k}+t_{000 l}+u_{00 k l}+r_{0 j k l}+e_{i j k l}
$$

This model can estimate the fraction of variability in performance associated with each level. Thus, belonging to a cluster or industrial concentration may only partly explain the variability existing among industry-city interactions $\left(\sigma_{u}^{2}\right)$. In estimating the fraction of this variability in relation to the 
total variance, an upper limit of the explanatory power of any variable that characterizes industry-city interactions is obtained. Although not resolving the issues regarding the difficulties of the empirical operationalization of concentrations, this methodology allows the estimation of the maximum potential for its explanatory power of performance, as long as the city is used as the unit of regional analysis and the 3-digit CNAE as the operationalization of industry.

The variance explained by each effect cannot be taken as a measure of its importance (Brush \& B romiley, 1997). In this study, the relative importance is calculated by the square root of the variance component, based on studies by Brush and Bromiley (1997), who conclude that "the importance of an effect is approximately the square root of the variance component" (pp. 833-834).

The inclusion of the CONC variable at level 3 allows testing the effect of belonging to an industrial concentration on the performance of industrial firms. At level 2, there are two control variables, the age and size of firms.

A ge was operationalized as the elapsed time (in years) from the founding of the company until the midpoint of the period observed in this study. For example, a firm established in the year 1960, with data from 1996 to 2004 in the SERA SA database, would be forty years old (mid-point of the observed period, i.e. 2000, subtracted from the founding date). The size was operationalized as the natural logarithm (In) of the firm's mean assets during the period of analysis, adjusted by the IGP-DI, a Brazilian inflation index, with values from December 1996 to offset the inflationary effects. By incorporating the age and size, at level 2 the model would be as follows:

\section{Level 2:}

$$
\pi_{0 j k l}=\beta_{00 k l}+\beta_{010} A g e+\beta_{020} L n_{-} \operatorname{size}+r_{0 j k l}
$$

where $\beta_{010}$ represents the estimate of the mean effect of age on the performance of firms, and $\beta_{020}$ represents the estimate of the mean effect of size on performance.

\section{Level 3:}

$$
\beta_{00 k l}=\gamma_{0000}+\gamma_{1000} C_{O N C} C_{k l}+s_{000 k}+t_{000 l}+u_{00 k l}
$$

where $\gamma_{1000}$ represents the estimate of the mean effect of industrial concentration on the performance of the firms.

A positive and significant coefficient would indicate a positive effect of industrial concentration on performance. Besides the model with ROA as the dependent variable, two other models were estimated with OpROA and ASSETURN, as the predicted variable.

The analysis of the effect of concentrations on the performance of firms has a considerable limitation: the estimated coefficient indicates the mean effect of industrial concentration on performance. Thus, while certain concentrations can bring exceptional performance to companies that are located within, others can cause the opposite effect. The estimation of the mean effect ignores this possibility, eliminating the idiosyncrasies of each concentration and, potentially indicating a null mean effect.

The effect of each concentration on the performance of its firms can be analyzed in the multilevel models by inspecting the residual of each industry-city interaction $\left(u_{00 k l}\right)$. This residual indicates whether the performance of firms in an interaction between an industry $\mathbf{k}$ and a city $\mathbf{I}$ is either above or below the expected value, given the industry and the city in which the firms operate. Positive and significant residuals will indicate a positive effect of some characteristic of that interaction (the industrial concentration, for example). The effect of such differences on performance could be studied by the prediction of the residual $u_{00 \mathrm{kl}}$. 
These residuals can be predicted by an empirical B ayesian estimator, which has the characteristic of shrinkage (it is biased towards the mean). Industry-city interactions with smaller samples tend to have unstable estimates of $t_{000 l}$. Thus, the lower the number of observations and the higher the variance of performance within the interaction, the greater the shrinkage of the estimator will be towards the mean and the higher the magnitude of prediction errors (Raudenbush \& Bryk, 2002).

This shrinkage, however, implies more efficient forecasts with lower standard errors and, consequently, narrower intervals of predictions (Snijders \& B osker, 1999). The predictions are also more appropriate when the number of cases in the lower level (firm) per unit of higher level (industrycity interaction) is small (Raudenbush \& Bryk, 2002).

After screening the SERASA database, the study proceeded to the analysis of multilevel models using the statistical software STATA ${ }^{\circledR}$, version 10 , in order to evaluate the effect of industrial concentrations on each performance indicator considered in this study.

\section{FINDINGS AND DISCUSSION}

The null model formalized in Equation 1 was estimated to decompose the variance of the performance of firms for the indicators ROA, OpROA and ASSETURN. Consistent with the findings of previous studies (Hough, 2006; Rumelt, 1991), the main determinants of performance (Table 1) were the effects related to levels 1 and 2 - time (approximately 70\% for ROA, and $62 \%$ for $0 \mathrm{pROA}$ $35 \%$ to A SSETURN) and firm ( $25 \%$ for ROA, 33\% for OpROA and $50 \%$ for A SSETURN). The high fraction of variance associated with time can be explained by the large time frame under study (10 years). A t higher levels, the effects related to the external environment (city, industry and industry-city interaction) account for a small fraction of the performance variance.

Table 1

Decomposition of the Performance V ariance

\begin{tabular}{|c|c|c|c|c|c|c|c|c|c|}
\hline & \multicolumn{3}{|c|}{ ROA } & \multicolumn{3}{|c|}{ OpROA } & \multicolumn{3}{|c|}{ ASSETURN } \\
\hline & Variance & $\begin{array}{c}\% \text { of } \\
\text { variance }\end{array}$ & $\begin{array}{l}\text { Relative } \\
\text { Importance }\end{array}$ & V ariance & $\begin{array}{c}\% \text { of } \\
\text { variance }\end{array}$ & $\begin{array}{l}\text { Relative } \\
\text { Importance }\end{array}$ & Variance & $\begin{array}{c}\% \text { of } \\
\text { variance }\end{array}$ & $\begin{array}{l}\text { Relative } \\
\text { Importance }\end{array}$ \\
\hline M unicipal & 3.220 & $0.73 \%$ & $5.07 \%$ & 10.913 & $1.86 \%$ & $7.74 \%$ & 0.078 & $5.76 \%$ & $12.21 \%$ \\
\hline Industry & 9.362 & $2.11 \%$ & $8.64 \%$ & 10.741 & $1.83 \%$ & $7.68 \%$ & 0.082 & $6.05 \%$ & $12.52 \%$ \\
\hline $\begin{array}{l}\text { Industry- } \\
\text { City } \\
\text { Interaction }\end{array}$ & 5.087 & $1.15 \%$ & $6.37 \%$ & 10.213 & $1.74 \%$ & $7.49 \%$ & 0.045 & $3.29 \%$ & $9.23 \%$ \\
\hline Firm & 111.273 & $25.07 \%$ & $29.80 \%$ & 192.847 & $32.93 \%$ & $32.55 \%$ & 0.680 & $50.19 \%$ & $36.06 \%$ \\
\hline Time & 314.862 & $70.95 \%$ & $50.12 \%$ & 360.881 & $61.63 \%$ & $44.53 \%$ & 0.470 & $34.72 \%$ & $29.99 \%$ \\
\hline
\end{tabular}

The effect of industry-city interaction accounted for $1.15 \%$ of the total variance of ROA, of $1.74 \%$ of OpROA and $3.28 \%$ of ASSETURN. This indicates that, however the variables may characterize industry-city interactions (these include industrial concentrations, industrial districts and clusters), they can explain at most approximately $3 \%$ of the total variability of performance between companies. These results suggest that the effect of location in industrial concentrations on the performance of industrial firms is limited. 
On the other hand, together, the relative importance (based on the square root of the variance components, as suggested by Brush \& Bromiley (1997), of the city and the industry-city interaction reaches approximately $12 \%$ of the ROA, $15 \%$ of OpROA and $22 \%$ of ASSETURN, suggesting that the location of firms and the way a city interacts with an industry exert considerable influence on how a firm will perform. In short, location matters greatly to the destiny of firms, which underlines the need to understand which characteristics specific to cities or regions could promote or retard the performance of their firms.

Next, the dummy variable CONC was included in the model. The statistical significance of its coefficient $\left(\gamma_{1000}\right)$ allowed the testing of the mean effect of industrial concentration on performance. Control variables age and In_size were also included. In relation to the variable CONC, Table 2 shows that the coefficients were positive for OPROA and ASSETURN, and negative for ROA, but statistically not significant ( $p$ values greater than 0.10 , as seen in the figures in parentheses). Therefore, sufficient evidence was not found to affirm that location within industrial concentrations provides companies with greater ROA, OpROA and asset turnover when compared to companies that are not located in industrial concentrations.

The control variable age proved to be significant at a level of $1 \%$ for ROA, OpROA and ASSETURN. In all three cases, the coefficient was negative, indicating that the companies' performances worsened as they grew older. As for the size (natural logarithm), this proved significant only for A SSETURN. The coefficients of the variable In_size were not specified in the table for the ROA and OpROA, as they were not significant.

Table 2

Coefficients of the M odel with the Variable CONC and Other C ontrol Variables

\begin{tabular}{ccccc}
\hline Variables & Coefficient & ROA & OPR OA & ASSETUR N \\
\hline \multirow{2}{*}{ CONC } & $\gamma 0000$ & 3.95 & 9.35 & 4.07 \\
& & $(0.000)$ & $(0.000)$ & $(0.000)$ \\
Ln_size & $\gamma 1000$ & -0.65 & 0.065 & 0.084 \\
& & $(0.789)$ & $(0.983)$ & $(0.622)$ \\
Age & 0010 & - & - & -0.114 \\
& & & & $(0.000)$ \\
& 00020 & -0.139 & -0.227 & -0.18 \\
& & $(0.006)$ & $(0.000)$ & $(0.000)$ \\
\hline
\end{tabular}

These results depend, however, on how the concentrations and the industries were operationalized, and the assumption that the effect of the concentrations on performance is relatively homogeneous. It is possible, however, that the effect of the concentrations is positive in some industrial concentrations and negative in others. B esides the fact that the companies are subject to the effects of the city and the industry to which they belong, there is also an effect resulting from the interactions that an industry has with a specific city, or the residual of each industry-city interaction $\left(u_{00 k l}\right)$.

The example of the furniture industry (CNAE 361) in the city of $V$ otuporanga sheds some light on the situation. All of the firms (of all industries) located in V otuporanga are subject to an effect specific to that city. All of the furniture companies of the state of São Paulo are subject to an effect resulting from the industry to which they belong. Finally, the location of the furniture industry in the city of $V$ otuporanga results in a specific effect on the interaction between industry and city, and it is possible that this effect is due to the existence of an industrial concentration in more complex stage of development, such as a cluster. 
Table 3 shows the specific effects (residuals) of the industry-city interactions characterized by the existence of concentrations. There is thus a synergetic effect of the location of the furniture industry in V otuporanga: 0.42 percentage points added to the expected value of ROA - besides the independent effects of being in $V$ otuporanga (city effect) and belonging to the furniture industry (industry effect). The effects of this interaction are also positive for the variables OpROA and A SSETURN.

M ost of the industry-city interactions listed in Table 3 have negative effects for each of the three indicators. The cities of J undiaí and V otuporanga are exceptions, showing positive effects of industrycity interactions for most indicators.

Table 3

Effects Specific to Industry-city Interactions Characterized by the Existence of Industrial Concentrations

\begin{tabular}{lcccc}
\hline \multicolumn{1}{c}{ City } & CNAE & ROA & OpROA & ASSETURN \\
\hline A mericana & 174 & -0.02 & -0.04 & -0.04 \\
Itapira & 245 & -0.39 & -0.57 & 0.05 \\
Jundiaí & 282 & 0.47 & 1.68 & 0.14 \\
Leme & 234 & -0.43 & -0.55 & -0.05 \\
Limeira & 294 & -0.29 & -0.44 & 0.02 \\
São J osé do Rio Preto & 282 & 0.06 & -0.05 & 0.06 \\
Sertãozinho & 282 & -0.18 & -0.53 & -0.10 \\
Sorocaba & 295 & -0.07 & -0.04 & -0.02 \\
Votuporanga & 361 & 0.42 & 0.59 & 0.02 \\
\hline
\end{tabular}

In the interaction between the furniture industry and Votuporanga, it is possible that the positive effects are a direct result of regional policy for the development of a cluster in the northwestern part of the state of São Paulo which, among other goals, aims to reduce operation costs by $5 \%$ and increase productivity and profitability by $20 \%$ in furniture companies that are part of this project (A ssociação Industrial da Região de Votuporanga [AIRVO], n.d.). However, several factors may explain the positive effects of this interaction, and the same applies to the interaction between the manufacturing industry of tanks, boilers and metal reserve tanks (CNAE 282) and the city of J undiaí.

Although the industry-city interaction mean effect was not significant, the relevance of the effects of industry-city interactions listed in Table 3 cannot be disregarded. In some of these interactions, these effects are not small. The cause of these effects may be analyzed by qualitative studies in these locations. J ust as it is important to know why the interactions associated with the cities of J undiai and V otuporanga have a positive effect on their businesses, it is also essential to understand why the opposite occurs in other interactions.

\section{FinAL CONSIDERATIONS}

This study examined the relationship between the geographic concentration of firms and their performance. It presented, as the main contribution, the use of multilevel models for analyzing the data, an appropriate technique for observations in hierarchical structures, as observed when studying industrial concentrations. 
Despite the lack of consensus on the definition and form of operationalization of industrial concentrations and clusters, all of these constructs relate to variables that are found at the level of industry-city interaction (or other definition of regional units, such as micro-region, for example).

The relative importance of city effects and industry-city interaction taken together (approximately $12 \%$ of the ROA, $15 \%$ of the OpROA and $22 \%$ of A SSETURN), clearly indicates that the location of firms and how a city interacts with an industry considerably influence how the firms will perform. In other words, location plays a key role in the destiny of companies, whether located in industrial concentrations or not.

The model used in this study also estimates the specific effects of each industry-city interaction characterized by the existence of industrial concentrations, opening up possibilities for further studies to seek to understand why the effects on the performance of firms tends to vary so much between interactions.

Some limitations of this study should be highlighted. The number of firms for interaction was small in many cases. The industry was operationalized by 3-digit CNAE, which can generate a bias of aggregation. M oreover, only one indicator of industrial concentration was used. Future studies could compare different forms of operationalizing industries and industrial concentrations and use larger samples.

Although companies' financial reports were obtained from a trustworthy institution in B razil, these data do not entirely reflect the reality of the national economy, characterized by a high number of companies that are not formally established (informal economy), which attempt to avoid high rates of taxation. Unfortunately, these companies are not included in official statistics, since it is difficult to obtain data and information about them.

However, some important academic and managerial implications should be considered. The geographical location, although important for the businesses, should also be accompanied by the development of resources specific to the businesses, as can be seen through the relative importance of the firm effect. Location matters and so do the specific resources of the firms.

In academic terms, the use of multilevel models demonstrated the potential that new methodologies that consider the nature of each variable can bring, contributing to the research field and opening avenues for further research.

\section{REFERENCES}

Appold, S. J. (1995). A gglomeration, interorganizational networks, and competitive performance in the u.s. M etalworking sector. Economic G eography, 71(1), 27-54.

A rikan, A. T. (2009). Inter-firm knowledge exchanges and the knowledge creation capability of clusters. Academy of M anagement Review, 34(4), 658-676.

Associação Industrial da Região de V otuporanga. (n.d.). Projeto moveleiro do noroeste paulista. (Technical Report/2007), V otuporanga, SP, A ssociação Industrial da R egião de V otuporanga.

A udretsch, D. B., \& Feldman, M. P. (1996). R\&d spillovers and the geography of innovation and production. The American Economic Review, 86(3), 630-640.

Becattini, G. (1991). Italian industrial districts: problems and perspectives. International Studies of $M$ anagement \& Organization, 21(1), 83-90. 
Benneworth, P. (2002). Creating new industries and service clusters on tyneside. Local Economy, 17(4), 313-327.

B oasson, V., B oasson, E., M acpherson, A., \& Shin, H. (2005). Firm value and geographic competitive advantage: evidence from the U.S. pharmaceutical industry. J ournal of Business, 78(6), 24652493.

B oschma, R. A ., \& Lambooy, J. G. (2002). K nowledge, market structure, and economic coordination: dynamics of industrial districts. Growth and Change, 33(3), 291-311.

Brakman, S., Garretsen, H., \& M arrevijk, C. van (2001). An introduction to geographical economics. Cambridge: Cambridge U niversity Press.

Brigham, E. F., Gapenski, L. C., \& Ehrhardt, M. C. (1999). Financial management: theory and practice (9th ed.). Orlando: Harcourt B race College Publishers.

Bristow, G. (2005). Everyone's a 'winner': problematising the discourse of regional competitiveness. J ournal of Economic Geography, 5(3), 285-304.

Brito, E. P. Z., B rito, L. A. L., Szilagyi, M . E., \& Porto, E. C. (2008, Setembro). A rranjos produtivos locais e crescimento. Anais do Encontro Nacional da Associação Nacional de Pós-Graduação e Pesquisa em Administração, Rio de J aneiro, RJ , Brasil, 32.

Britto, J., \& Albuquerque, E. M. (2002). Clusters industriais na economia brasileira: uma análise exploratória a partir de dados da RAIS. Estudos E conômicos, 32(1), 71-102.

Brush, T. H., \& Bromiley, P. (1997). What does a small corporate effect mean? A variance components simulation of corporate and business effects. Strategic Management Journal, 18(10), 825-835.

Caner, T., \& Hall, M. (2006, A ugust). Geographical location, social capital, and innovation in the US biopharmaceutical industry. Academy of Management M eeting Proceedings, A tlanta, Georgia, USA.

Chung, W ., \& K alnis, A. (2001, October). A gglomeration effects and performance: a test of the Texas lodging industry. Strategic M anagement J ournal, 22(10), 969-988.

Corolleur, F., \& Courlet, C. (2003, October). The marshallian industrial district, an organizational and institutional answer to uncertainty. Entrepreneurship \& Regional D evelopment, 15(4), 299-307.

Crocco, M. A., Galinari, R., Santos, F., Lemos, M. B., \& Simões, R. (2006). M etodologia de identificação de aglomerações produtivas locais. Nova E conomia, 16(2), 211-241.

Dekle, R. (2002). Industrial concentration and regional growth: evidence from the prefectures. The Review of Economics and Statistics, 84(2), 310-315.

Fallick, B., Fleischman, C. A ., \& Rebitzer, J . B. (2006). J ob-hopping in silicon valley: some evidence concerning the microfoundations of a high-technology cluster. The Review of Economics and Statistics, 88(3), 472-481.

Federação das Indústrias do Estado de São Paulo. (2008). M anual de atuação em arranjos produtivos locais - APLs. Retrieved September 18, 2008, from http://www.fiesp.com.br/competitividade/downloads/manual_apl.pdf

Ferreira, F. C. M. (2005). 0 efeito da aglomeração industrial no desempenho econômico das firmas: uma análise exploratória aplicada ao setor de confecções do Estado de São Paulo. Master's degree dissertation, Fundação G etúlio V argas, São Paulo, SP, B rasil. 
Feser, E. J., \& Bergman, E. M . (2002). National industry cluster templates: a framework for applied regional cluster analysis. Regional Studies, 34(1), 1-19.

Floysand, A ., \& J akobsen, S. (2002). Clusters, social fields, and capabilities: rules and restructuring in norwegian fish-processing clusters. International Studies of Management \& Organization, 31(4), 35-55.

George, V. P., \& Zaheer, A . (2006, September). Geographic signatures: proximites and performance. Proceedings of the Strategic M anagement Society M eeting. V ienna, A ustria.

Gitman, L. J . (2001). Princípios de administração financeira essencial. Porto A legre: Bookman.

Goldszmidt, R. G. B., Brito, L., \& Vasconcelos, F. C. (2007). 0 efeito país sobre o desempenho da firma: uma abordagem multinível. Revista de Administração de Empresas, 47(4), 12-25.

Hakanson, L. (2004, A ugust). E pistemic communities and cluster dynamics: on the role of knowledge in industrial districts. Academy of M anagement M eeting Proceedings. N ew Orleans, USA

Hanson, G. H. (2001). Scale economies and the geographic concentration of industry. J ournal of Economic Geography, 1(3), 255-276.

Henderson, V., Kuncoro, A., \& Turner, M. (1995). Industrial development in cities. Journal of Political Economy, 103(5), 1067-1090.

Hoen, A. (2000). Three variations on identifying clusters. Retrieved April 15, 2008, from http://www.oecd.org/dataoecd/34/41/2099308.pdf

Hoffman, D. A . (1997). A n overview of the logic and rationale of hierarchical linear models. J ournal of M anagement, 23(6), 723-744.

Holmes, T. J ., \& Stevens, J. J . (2002). G eographic concentration and establishment scale. The Review of Economics and Statistics, 84(4), 682-690.

Hoover, E. M . (1948). The location of economic activity. New Y ork: M cGraw-Hill.

Hough, J. R. (2006). Business segment performance redux: a multilevel approach. Strategic M anagement J ournal, 27(1), 45-61.

Hox, J. (2002). Multilevel analysis: techniques and applications. Mahwah, NJ: Lawrence Erlbaum A ssociates.

Instituto Paranaense de Desenvolvimento Econômico e Social. (2005). Arranjos produtivos locais do Estado do Paraná: identificação, caracterização e construção de tipologia. Retrieved February 17, 2008, from http://www.ipardes.gov.br/webisis.docs/apl_identificacao_tipologia_etapa_1.pdf

Ketelhohn, N. W. (2002). The role of cluster as sources of dynamic externalities. Doctoral dissertation, Harvard B usiness School, Cambridge, M assachusetts, U nited States.

Kotval, Z., \& M ullin, J. (1998). The potential for planning an industrial cluster in Barre, Vermont: a case of "hard-rock" resistance in the granite industry. Planning Practice \& Research, 13(3), 311-318.

K rugman, P. (1991). Geography and trade. Cambridge: The M IT Press.

K rugman, P. (1993). First nature, second nature, and metropolitan location. J ournal of Regional Science, 33(2), 129-144.

Malmberg, A., \& Power, D. (2005). (How) do (firms in) clusters create knowledge? Industry \& Innovation, 12(4), 409-431. 
M arshall, A . (1985). Princípios de economia: tratado introdutório (V ol. 2). São Paulo: Nova Cultural.

M artin, R., \& Sunley, P. (1996). Paul krugman's geographical economics and its implications for regional development theory: a critical assessment. Economic G eography, 72(3), 259-292.

M artin, R ., \& Sunley, P. (2003). Deconstructing clusters: chaotic concept or policy panacea? J ournal of Economic G eography, 3(1), 5-35.

Mcgahan, A. M., \& Porter, M. E. (1997). How much does industry matter, really? Strategic M anagement J ournal, 18(Summer Special Issue), 15-30.

Meardon, S. J. (2000). Eclecticism, inconsistency, and innovation in the history of geographical economics. History of Political Economy, 32(4), 325-359.

M olina-M orales, F. X ., \& M artínez-Fernández, M . T. (2003). The impact of district affiliation on firm value creation. European Planning Studies, 11(2), 155-170.

Mori, T., Nikishimi, K., \& Smith, T. E. (2005, November). A divergence statistic of industrial localization. The Review of Economics and Statistics, 87(4), 635-651.

Pietrobelli, C., \& Barrera, T. 0. (2002). Enterprise clusters and industrial districts in colombia's fashion sector. European Planning Studies, 10(5), 541-562.

Porter, M. E. (1998a). Clusters and the new economics of competition. Harvard Business Review, 76(6), 77-90.

Porter, M. E. (1998c). On competiton. B oston: Harvard Business School Publishing.

Porter, M . E. (1998b). The A dam Smith address: location, clusters, and the "new" microeconomics of competition. Business Economics, 33(1), 7-13.

Porter, M . E. (2003).The economic performance of regions. Regional Studies, 37(6/7), 549-578.

Pouder, R., \& John, C. H. (1996). Hot spots and blind spots: geographical clusters of innovation. Academy of M anagement Review, 21(4), 1192-1225.

Puga, F. P. (2003). Alternativas de apoio M PMES localizadas em arranjos produtivos locais [Texto para discussão, № 99]. Retrieved January 17, 2008, from http://www.bndes.gov.br/conhecimento/td/Td-99.pdf

Raudenbush, S. W., \& Bryk, A. S. (2002). Hierarchical linear models: applications and data analysis methods. Thousand Oaks, CA: Sage.

Rumelt, R. P. (1991). How much does industry matter? Strategic Management J ournal, 12(3), 167185.

Sakakibara, M ., \& Porter, M . E. (2001). Competing at home to win abroad: evidence from J apanese industry. The Review of E conomics and Statistics, 83(2), 310-322.

Saxenian, A. (1996). Regional advantage: culture and competition in silicon valley and route 128. Cambridge, M A : Harvard University.

Scitovsky, T. (1954). Two concepts of external economies. The J ournal of Political Economy, 62(2), 143-151.

Serviço de A poio às M icro e Pequenas Empresas de São Paulo. (2002). Subsídios para a identificação de clusters. Retrieved July 31, 2008, from http://www.biblioteca.sebrae.com.br/bds/BD S.nsf/9FF 9548D A B 02E 8B 4832572C 20056D 8C 3/\$ File/NT000351B6.pdf 
Short, J. C., K etchen, D. J., J r., Palmer, T. B ., \& Hult, G. T. M. (2007). Firm, strategic group, and industry influences on performance. Strategic M anagement J ournal, 28(2), 147-167.

Snijders, T. A. B ., \& Bosker, R. J . (1999). M ultilevel analysis: an introduction to basic and advanced multilevel modeling. London: Sage Publications.

Suzigan, W., Furtado, J., Garcia, R., \& Sampaio, S. E. K. (2003, Dezembro). Sistemas locais de produção: mapeamento, tipologia e sugestões de políticas. Encontro Nacional de Economia, Porto Seguro, B A, B rasil, 31.

V an Der Linde, C. (2002). Findings from the cluster meta-study. Harvard Business School, Institute for Strategy and Competitiveness. Retrieved March 28, 2008, from http://www.isc.hbs.edu/M etaStudy2002prz.pdf

V om Hofe, R., \& Chen, K. (2006). Whiter or not industrial cluster: conclusion or confusions? The Industrial Geographer, 4(1), 2-28.

White, G. I., \& Sondhi, A. C. (1997). The analysis and use of financial statements (2nd ed.) New Y ork: Wiley.

Y ou, J., \& Wilkinson, F. (1994). Competition and co-operation: toward understanding industrial districts. Review of Political Economy, 6(3), 259-278. 